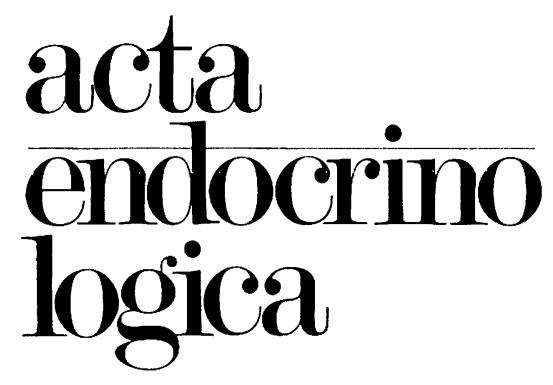




\section{HYPOTHALAMUS}

Kalra S. P. \& Kalra P. S.: Dynamic changes in hypothalamic LH-RH levels associated with the ovarian steroid-induced gonadotrophin surge $\ldots \ldots \ldots \ldots \ldots$ Morishita H., Nakago K., Ii K., Hashimolo T., Kawamolo M., Tanaka T., Higuchi K. Miyauchi Y. \& Ozasa T.: Anovulation and oviductal hyperplasia in rats treated with clomiphene citrate 5 days after birth ..................

\section{PITUITARY}

Balogh A., Robertson D. M. \& Diczfalusy' E.: Effect of the norethisterone minipill

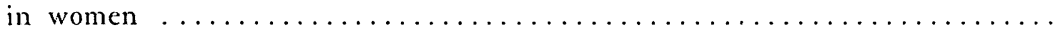

Baumann R. \& Kuhl H.: Interaction of [125I] LH-RH and other oligopeptides with plasma membranes of rat anterior pituitaries $\ldots \ldots \ldots \ldots \ldots \ldots \ldots \ldots \ldots$ Bohnet H. G., Hanker J. P., Horowski R., Wickings E. J. \& Schneider H. P. G.: Suppression of prolactin secretion by lisuride throughout the menstrual cycle and in hyperprolactinaemic menstrual disorders $\ldots \ldots \ldots \ldots \ldots \ldots \ldots \ldots \ldots$

Carlson J. C. \& Kehl S. J.: Prostaglandin-stimulated $\mathrm{LH}$ release in cyclic and

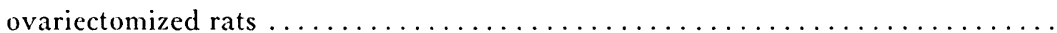

de Koning J., van Dieten J. A. M. J., Tijssen A. M. I. \& van Rees G. P.: Studies on a protein synthesis dependent step in LH relcase by LH-RH ...........

Eversmann T., Fahlbusch R., Rjosk H. K. \& von Werder K.: Persisting suppression of prolactin secretion after long-term treatment with bromocriptine in patients

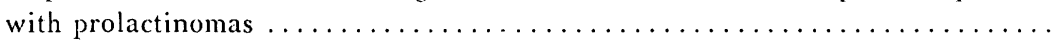

Golstein J., Vanhaelst L., Bruno (). D. \&. L'Hermile M.: Effect of cyproheptadine on thyrotrophin and prolactin secretion in normal man $\ldots \ldots \ldots \ldots \ldots \ldots$

Jaques, Jr. S. \& Gala R. R.: The influence of oestrogen administration in vivo on

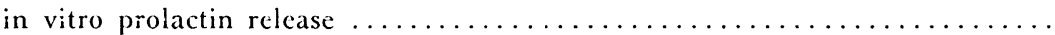

Koiter T. R., Pols-Valkhof N., Zürcher A. F. \& Schuilling G. A.: LH-secretory responses caused by continuous infusion of LH-RH in pseudopregnant rats ...

L'Hermile M., Michaux-Duchêne A. \& Robyn C.: Tiapride-induced chronic hyperprolactinacmia: interference with the human menstrual cycle ............

Marana R., Robertson D. M., Suginami H. \& Diczfalusy' E.: The assay of human follicle-stimulating hormone preparations: the choice of a suitable standard ....

Marana R., Suginami H.. Robertson D. M. \& Diczjalusy E.: Inlluence of the purity of the iodinated tracer on the specificity of the radioimmunoassay of human

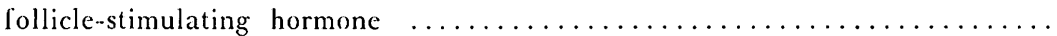


Peilon F., Philippon J., Brandi A. M., Fohemno D., Lapienc D.. Dubois M. P. \& Decourt $J .:$ Prolactin-secreting pituitary adenoma in a man with gigantism:

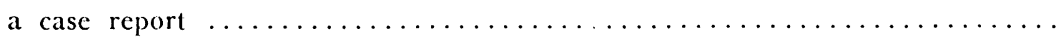

Pirke K. M., Fichler M. M., Lund R. \&. Doerr P.: Twenty-four hour sleep-wake pattern of plasma $\mathrm{LH}$ in patients with anorexia nervosa $\ldots \ldots \ldots \ldots \ldots \ldots$

Robertson D. M., Puri V., Lindberg M. \& Diczfalusy E.: Biologically active lutei-

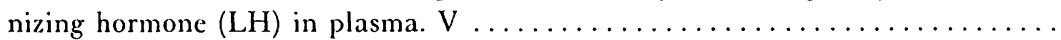

Sato T. \& Uchigata $Y$.: Long-term effects of human growth hormone on plasma

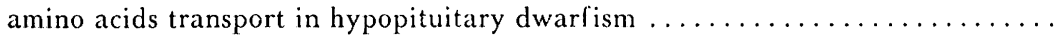

Schams D., Schmidt-Polex B. \& Kruse V.: Oxytocin determination by radioim-

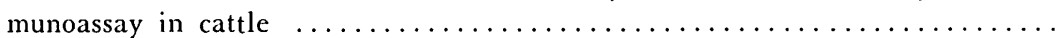

Schuilling G. A., Pols-Valkhof N. \& Koiter T. R.: A possible role of corpora lutea with regard to oestrogen-induced changes in pituitary responsiveness to LH-RH

Spitz I. M., Trestian S., Cohen H., Arnon N. \& LeRoith D.: Failure of metoclopramide to inlluence $\mathrm{LH}, \mathrm{FSH}$ and $\mathrm{TSH}$ secretion or their responses to releasing

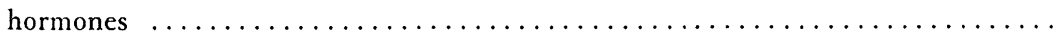

Takano K., Hizuka N., Shizume K. \& Hasumi Y.: Serum levels of somatomedin A and growth during long-term treatment of patients with pituitary dwarfism with

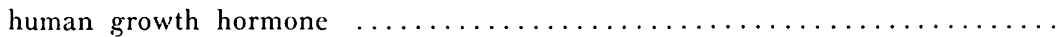
van Buul-Offers S. \& Van den Brande J. L.: Elfect of growth hormone and peptide fractions containing somatomedin activity on growth and cartilage met-

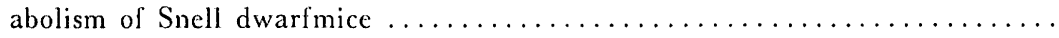

Zárate A., Cunales E. S., Alger M. \& Forsbach G.: The effect of pregnancy and lactation on pituitary prolactin-secreting tumours $\ldots \ldots \ldots \ldots \ldots \ldots \ldots$

\section{THYROID}

Afrasiabi A., Valenla L. \& Gininup G.: A TSH secreting pituitary tumour causing hyperthyroidism: presentation of a case and review of the literature ......... liurger A. G., Engler D., Sakoloff C. \& Stacheli $V .:$ The effects of tetraiodithyroacetic and triiodothyroacetic acids on thyroid function in euthyroid and hyper-

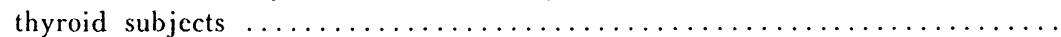

Carpi A., Bianchi R., Zucchelli G. C.. Del Corso L.. Levanti C., Cocci F. Giamnessi D. \& Mariani $G .:$ Effect of endogenous thyroid stimulating hormone levels on

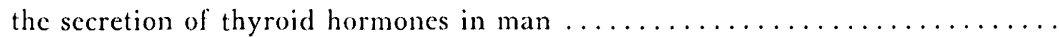

Czarnocka B., Nauman J., Adler G. \& Kiclczyniski W.: Solubilization and partial characterization of thyroid membrane TSH binding proteins $\ldots \ldots \ldots \ldots \ldots$

Dietrich F. M.. Fischer J. A. \& Bijuoct O. L. M.: Formation of antibodies to synthetic human calcitonin during treatment of Paget's disease ...............

Hacberli A., Engler H., von Grünigen C.. Kohler H. \& Studer H.: Low molecular weight intracellular iodocompounds with long intrathyroidal half-life: remnants

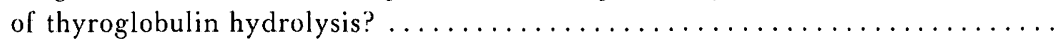

Hamada S. \& Nishimoto M.: Inhibitory effect of certain drugs on thyroid hormone

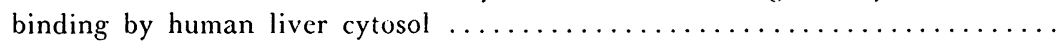

Medeiros-Neto G. A., Knobel M.. Bronstein M. D., Simonetti J., Filho F. F. \&. Matlar E.: Impaired cyclic-AMP responsc to thyrotrophin in congenital hypothyroidism with thyroglobulin deficiency $\ldots \ldots \ldots \ldots \ldots \ldots \ldots \ldots \ldots \ldots \ldots \ldots$ 
Okamura K., Inoue K., Nakashima T., Shiroozu A. \& Yoshinari M.: Iodoamino acid synthesis in thyroid lobes in vitro with excellent yield of iodothyronines ..

Spira O., Birkenfeld A., Gross J. \& Gordon A.: TSH synthesis and relcase in the

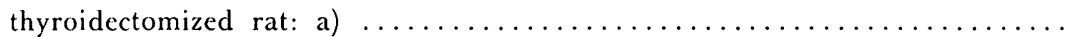

Spira O., Birkenfeld A., Avni A., Gross J. \& Gordon A.: TSH synthesis and release

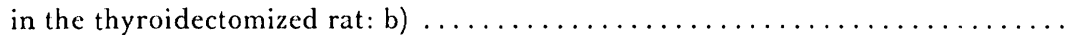

Suzuki H., Kadena N., Takeuchi K. \& Nakagatea S.: Effects of three-day oral cholecystography on serum iodothyronines and TSH concentrations: comparison of the effects among some cholecystographic agents and the effects of iopanoic

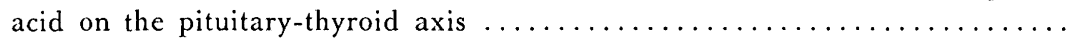

Theilade P., Molholm Hansen J., Skovsted L. \& Kampmann J. P.: Effect of exercise on thyroid parameters and on metabolic clearance rate of antipyrine in man

Toccafondi R. S., Rotella C. M., Tanini A., Fani P. \& Arcangeli P.: Thyrotrophinresponsive adenylate cyclase activity in thyroid toxic adenoma ............

Wallace A. L. C., Nancarrow C. D., Evison B. M. \& Radford H. M.: The effect of thyrotrophin releasing hormone on pituitary and thyroid function in pre- and

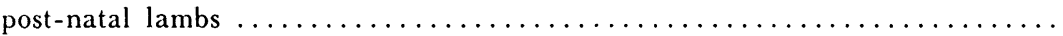

Wilkin T. J., Gunn A., Isles T. E., Crooks J. \& Swanson Beck J.: The behaviour of the thyroidal iodide trap after subtotal thyroidectomy for thyrotoxicosis and

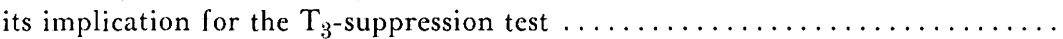

Walinder O.. Karlsson F. A. \& Dahlberg P. A.: Adenyl cyclase activity in human thyroid plasma membranes from normal human thyroid tissue and thyroid

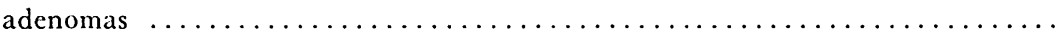

\section{P A R A T H Y R O I D}

Iuss M., Bergans A., Geurts J., Brauman H. \& Corvilain J.: Effect of rapid variation of renal function on plasma calcitonin and parathyroid hormone in man ..

Halse J. \& Gordeladze J. O.: Urinary excretion of calcium, hydroxyproline and $3^{\prime}, 5^{\prime}$-cyclic adenosine monophosphate in primary hyperparathyroidism ........ Wilke R., Harmeyer J., von Grabe C., Hehrmann R. \& Hesch R. D.: Regulatory hyperparathyroidism in a pig breed with vitamin $\mathrm{D}$ dependency rickets .......

\section{MAM MARY GLANDS}

Jorgensen $O$. G., Ekeland A. \& Gautvik K. M.: Serum and tissue concentrations of immunoreactive calcitonin in patients with breast tumours $\ldots \ldots \ldots \ldots \ldots$

\section{PANCREAS}

Boquist L.: Differences in the blood glucose response of mice to alloxan and al-

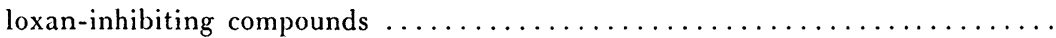
Järhult J., Ahrén B. \& Lundquist I.: Inhibitory effect of somatostatin on insulin secretion during $\alpha$-adrenergic blockade in three different species $\ldots \ldots \ldots \ldots \ldots$ 
Lenz S., Kühl C. Wang P.. Molsled-Pedersen L., Orskov H. \& Faber O. K.: The effect of ritodrine on carbohydrate and lipid metabolism in normal and diabetic

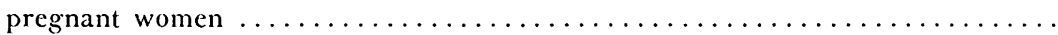

Schusdziarra V., Rouiller D. \& Unger R. H.: Sympathectomy and prostaglandin deliciency do not prevent gastrogenic hyperglycaemia and hyperinsulinaemia .

Turner R. C., Harris E., Ounsted M. \& Ponsford C.: Two abnormalities of gluceseinduced insulin secretion: dose-response characteristics and insulin sensitivity ..

\section{LIVER}

Furuhashi $N$. \& Fang $V$. S.: Sex difference in the induction of lactogenic receptors

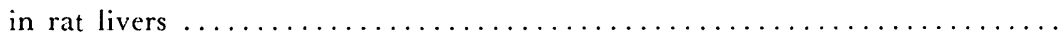

Takaishi M., Shimizu T. \& Shishiba Y.: Solubilization of thyroxine-5'-deiodinase activity from rat liver micresome fraction $\ldots \ldots \ldots \ldots \ldots \ldots \ldots \ldots \ldots \ldots \ldots$

\section{A D R ENALS}

Alvarez-Buylla $R$. \& Tsutsumi $V .:$ Adrenocortical function in hypophysectomized dogs with parotid gland transplants in direct contact with the basal hypothalamus

Gaillard R. C., Riondel A., Merkelbach U. \& Vallotlon M. B.: Changes in plasma aldosterone following the administration of various combinations of stimuli ....

Sarula T., Okuno T., Eguchi T., Nakamura R., Saito I., Kondo K.. Oka M. \&. Malsuki S.: Responses of aldostcrone-producing adenomas to ACTH and angiotensins

Zachmann $M$. \& Prader A.: Unusual heterozygotes of congenital adrenal hyperplasia due to 21-hydroxylase deficiency confirmed by HL.A tissue typing ......

\section{OVARIES}

Lillienberg L., Adlercreutz H. \& Svanborg A.: Effect of a sequential oestrogenprogestin therapy on the plasma level of ocstrogens and lipids in post-menopausal women

\section{UTERUS}

Jorgensen J.: The mechanism of the acid activation of rabbit uterine renin ..... Jorgensen J.: Inactivation of renin in a mixed mitochondrial-lysosomal fraction

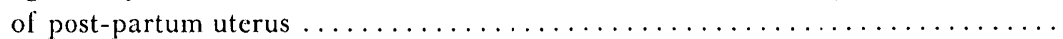

\section{PREGNANCY}

Belleville F., Lasbennes A., Nabet P. \& Paysant P.: HCS regulation in cultured

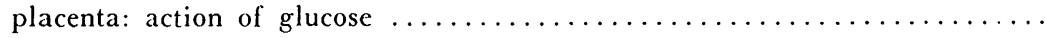


Kreitmamn $B$. \& Bayard $F .:$ Oestrogen and progesterone receptor concentrations in

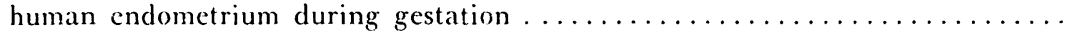

Lund B. \& Selne's A.: Plasma 1,25-dihydroxyvitamin D levels in pregnancy and

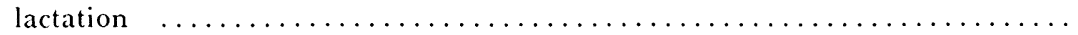

Reck G.. Renner A., Sinns G. \& Breckwoldt M.: Correlation of plasma non-conjugated oestriol and plasma cortisol in late human pregnancy ..............

Rigaudiere $N .:$ The androgens in the guinea-pig foetus throughout the embryonis

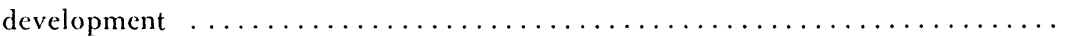

\section{TESTES}

Larbarino A. \& De Marinis L.: Klinefelter's syndrome: effects of oestrogen on growth hormone, prolactin and thyrotrophin release, and on thyrotrophin and prolactin responses to thyrotrophin-releasing hormone $\ldots \ldots \ldots \ldots \ldots \ldots \ldots$

pirke K. M., Krings B. \& Vogı H.-J.: Further studies on hypothalamic-pituitary-

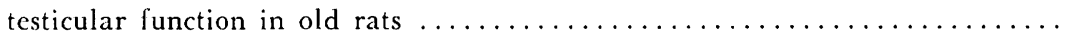

\section{MISCELLANEOUS}

Becker K. L., Snider R. H., Moore C. F., Monaghan K. G. \& Silva O. L.: Calcitonin

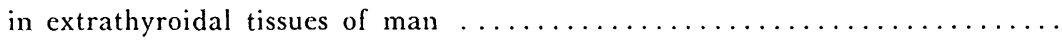
Bernulz C., Hänsle W. O., Horn K., Pickardt C. R., Scriba P. C., Fink E., Kolb H. \&. Tschesche $H$.: Isolation, characterization and radioimmunoassay of corticosteroid-binding globulin (CBG) in human serum - clinical significance and comparison to thyroxine-binding globulin (TBG) $\ldots \ldots \ldots \ldots \ldots \ldots \ldots \ldots \ldots$

Larkin L. H., Suarez-Quian C. A. \& Fields P. A.: In vitro analysis of antisera to

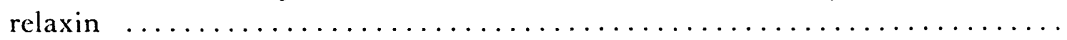

Pernitcheva-Rostaing E., Fonlagné J., Adolphe M., Engellman Ph., Morin P. \&. Le'chat $P$.: Effect of human chorionic gonadotrophin on phagocytic activity and proliferative capacity of rat peritoneal macrophages in culture .............

Wambach G., Higgins J. R., Kem D. C. \& Kaufmann W.: Interaction of synthetic progestagens with renal mineralocorticoid receptors $\ldots \ldots \ldots \ldots \ldots \ldots \ldots$ 
Medizinische Klinik Innenstadt der Universität, Ziemssenstraße 1, D-8000 München 2, FRG

\title{
ISOLATION, CHARACTERIZATION AND RADIOIMMUNOASSAY OF CORTICOSTEROID-BINDING GLOBULIN (CBG) IN HUMAN SERUM - CLINICAL SIGNIFICANCE AND COMPARISON TO THYROXINE-BINDING GLOBULIN (TBG)
}

\author{
By \\ C. Bernutzil), W. O. Hänsle, K. Horn, C. R. Pickardt, P. C. Scriba, E. Fink ${ }^{11}$, \\ H. Kolb ${ }^{2)}$ and H. Tschesche ${ }^{3)}$
}

\begin{abstract}
A B S T R A C T
Isolation of the corticosteroid-binding globulin $\mathrm{CBG}$ was achieved by 5 chromatographical steps on cortisol Sepharose, QAE-Sephadex A-50, Con A-Sepharose and hydroxylapatite. The purity of the isolated CBG was demonstrated in polyacrylamide gel electrophoresis, SDS electrophoresis, immunodiffusion and ultracentrifugation. Microheterogeneity was shown in isoelectric focusing by 5 bands in the $\mathrm{pH}$ range of $3.7-4.2$, which could be reduced to one major band after neuraminidase treatment. The equimolar binding of cortisol to CBG was demonstrated by binding studies. The association constant for cortisol was $2.8 \times 10^{8} \mathrm{M}^{-1}$, for progesterone
\end{abstract}

1) Abteilung für Klinische Chemie und Klinische Biochemie der Chirurgischen Klinik der Universität, Nußhaumstraße 20, D-8000) München 2.

2) Forschergruppe Diabetes, Städtisches Krankenhaus München-Schwabing, Kölner Platz, D-8000 München 40,

3) Fakultät für Chemie der Universität Bielefeld, Universitätsstraße, D-4800 Bielefeld 1

Dedicated to Professor Dr. rer. nat. Dr. med. h.c. Theodor Bücher at the occasion of his 65 th birthday.

Supported by Deutsche Forschungsgemeinschaft (SFB 51).

a) Preliminary results were presented in part at the 22nd Symposium of the Deutsche Gescllschaft für Endokrinologie, Travemünde, 1977.

C. B. was awarded with the "Marius-Tausk"-Prize of the Deutsche Gesellshaft für Endokrinologie 1978 for this work.

Abbreviations used in this paper:

$\mathrm{CBG}$, corticosteroid-binding globulin; TBG, thyroxine-binding globulin. 
$1.7 \times 10^{6} \mathrm{M}^{-1}$. From analytical ultracentrifugation, the molecular weight was calculated on 50700 ; the sedimentation coefficient was $3.6 \mathrm{~S}$, the partial specific volume $0.690 \mathrm{ml} / \mathrm{g}$, the Stokes radius $38 \AA$ and the frictional coefficient ratio 1.5 .

A specific radioimmunoassay for CBG was established using the purified CBG for immunization, radioiodination and for calibration standards. The normal range of $\mathrm{CBG}$ levels in human serum was $2.4-4.4 \mathrm{mg} / 100 \mathrm{ml}$ (mean $\pm 2 \mathrm{sD}$ ). Studies were performed to compare the levels of $\mathrm{CBG}$ and thyroxine-binding globulin (TBG). No sex differences but a significant biphasic age dependence werc observed for both proteins. In pregnancy and under oestrogen treatment of women and men, CBG was demonstrated to be the more distinct indicator of oestrogenic activity as compared with TBG, whereas the sensitivity of TBG was more pronounced to supposedly antioestrogenic substances like Danazol, and in severe disease. No coincidence of genetic CBG and TBG deficiencies have been found so far.

In human serum, cortisol is bound to a specific transport protein, corticosteroidbinding globulin $(\mathrm{CBG})$ or transcortin, with high affinity and low capacity which migrates on paper electrophoresis as an alpha ${ }_{1}$-globulin. In addition cortisol is bound to albumin which has low affinity, but high capacity (Daughailay 1956a,b; Slaunwhile \& Sandberg 1959; Slaunzohile et al. 1966; Muldoon \&. Westphal 1967).

The concentration of CBG was until now estimated by measuring the total binding capacity of serum for cortisol using gel filtration and equilibrium dialysis (De Moor el al. 1962; Murphy \& Pattee 1963; Westphal 1971; Schreartz \&: Hammerstein 1975; Angeli el al. 1977), and recently more specifically by radial immunodiffusion (Rosner el al. 1973; Racadot el al. 1974; Van Baelen c. De Moor 1974). There is major evidence that CBG has a buffer function for the biologically active free hormone fraction in blood (Slaunwelite et al. 1962; De Moor et al. 1963; Sandberg \& Slaunzelite 1963), rather than an active transport function for steroid hormones to the target organ cell. But a possible role of proteins in hormone-receptor interactions is also discussed (Westphal 1971; Werthamer et al. 1973; Wong et al. 1973). The CBG concentrations in human serum have been estimated mainly under the aspect of oestrogen influence (Sandberg \& Slaunwhile 1959; De Moor el al. 1962; Doe el al. 1964; Schwartz \& Hammerstein 1975) and genetic deficiency variations (Rosner el al. 1973).

Recently, characteristic changes of the thyroxine-binding globulin (TBG) have been demonstrated under the influence of different metabolic conditions (Horn et al. 1977; Horn \& Gärtner 1979). Therefore, it was investigated, whether parallelism in changes of these two different transport proteins, CBG and TBG could be detected.

For this purpose $\mathrm{CBG}$ had to be isolated from human serum and a specific method for its determination had to be established. 
Reagents. - Pure cortisol was purchased from the Merck AG, Darmstadt, FRG, [3H] cortisol $(110 \mathrm{mCi} / \mathrm{mg}$ cortisol) from the Radiochemical Center in Amersham, England, and cortisol hemisuccinate from Sigma Chemical Company, St. Louis, USA. Sodium 12: iodide $(10 \mathrm{Ci} / \mathrm{mg}$ I) came from the Hoechst AG, Frankfurt, FRG. AH-Sepharose 4B for affinity chromatography, Con A-Sepharose, QAE-Sephadex A-50 for ion exchange chromatography and Sephadex G-10 were obtained from Pharmacia Fine Chemicals, Uppsala, Sweden. The hydroxylapatite Biogel HTP was purchased from Bio-Rad Laboratories, Richmond, USA. Florisil, acrylamide and bovine gamma globulin were obtained from the Serva Biochemica, Heidelberg, FRG. Sodium Lauryl Sulphate (SDS) from Sigma Chemical Company, St. Louis, USA. Bovine albumin and alpha-methylD-mannoside from Roth, Karlsruhe, FRG, neuraminidase (clostridium perfringens) from Boehringer Mannheim GmbH. The following reagents came from the Merck AG, Darmstadt, FRG: N-ethyl-N'-(3-dimethylaminopropyl)-carbodiimide-hydrochlorid, polyethylenglycol 6000, complete Freund's adjuvant and all reagents (pro-analysis grade) for the preparation of the buffer solutions. Human transferrin and pertussis vaccine were obtained from the Behringwerke, Marburg, FRG. The human plasma anticoagulated with acid-citrate-dextrose (ACD) was freshly obtained from the blood bank and immediately used for preparation.

Isoelectric focusing. - Isoelectric focusing studies (Radola \& Graesslin 1977) of isolated CBG were performed in slab gels $(16 \times 0.4 \mathrm{~cm})$, using $\mathrm{LKB}$ equipment (LKB produkter, Bromma, Sweden). The concentrations of polyacrylamide and Ampholine ${ }^{8}$ solutions $\mathrm{pH} 3.5-5.0$ and $\mathrm{pH} 3.5-10$ respectively (LKB produkter) were each $5 \%(\mathrm{v} / \mathrm{v})$. After isoelectric focusing ( $500 \mathrm{~V}, 20 \mathrm{~W}, 6$ hours) gels wcre cither stained using bromophenol blue or cut in slices of $0.5 \mathrm{~cm}$. After elution with destilled water by diffusion $\mathrm{pH}$-values were measured with a microelectrode, the CBG-concentrations by radioimmunoassay and $[3 \mathrm{H}]$ cortisol in a $\beta$-scintillation counter.

\section{Isolation of CBG from human plasma}

Affinity chromatography. - Using a modification of the method described by Cuatrecasas (1970), $2 \mathrm{~g}$ cortisol hemisuccinate $(=4.1 \mathrm{mmol})$ dissolved in $50 \%$ dimethylformamide were covalently bound to $15 \mathrm{~g}$ AH-Sepharose $4 \mathrm{~B} \quad(=0.48 \mathrm{mmol}$ amino groups) by activation with $2.17 \mathrm{~g}$ carbodiimide $(=10 \mathrm{mmol})$ for $20 \mathrm{~h}$ at room temperature. The cortisol Sepharose was then washed alternatively with $1 \mathrm{M}$ glycine and $0.2 \mathrm{M}$ Tris-HC1 buffer $\mathrm{pH}$ 8.6. From 5 liters human plasma the endogenous steroids were removed by $50 \mathrm{~g}$ florisil. Then, plasma and cortisol Sepharose were stirred for $30 \mathrm{~min}$ at room temperature and for $60 \mathrm{~min}$ at $4^{\circ} \mathrm{C}$. The plasma was then filtered, the gel was washed with $1000 \mathrm{ml}$ cold $0.2 \mathrm{M}$ Tris- $\mathrm{HCl}$ buffer $\mathrm{pH} 8.0$ and packed in a waterjacketed column. From this column CBG was eluted by elevation of the temperature up to $30^{\circ} \mathrm{C}$ with $20 \mathrm{mg}$ cortisol hemisuccinate in $100 \mathrm{ml} 0.16 \mathrm{M} \mathrm{NaCl}$ in $0.05 \mathrm{M}$ TrisHC1 buffer $\mathrm{pH} 8.6$.

\section{Purification of CBG by column chromalography lechniques}

The following purification steps were performed at $4^{\circ} \mathrm{C}$. The $\mathrm{CBG}$ peak from cortisol Sepharose was given on a QAE-Sephadex A-50 column $(4.2 \times 24 \mathrm{~cm})$ which was equilibrated with $0.18 \mathrm{M} \mathrm{NaCl}$ in $0.05 \mathrm{~m}$ Tris- $\mathrm{HCl}$ buffer $\mathrm{pH}$ 8.6. After washing the gel with one column volume of starting buffer, $\mathrm{CBG}$ was eluted by the elevation of the $\mathrm{NaCl}$ concentration up to $0.22 \mathrm{M}$ in $0.05 \mathrm{~m}$ Tris-HCl buffer $\mathrm{pH} 7.4$ in a volume of 
$90 \mathrm{ml}$. This CBG peak was transferred on a Con $A$-Sepharose column $(3.2 \times 22 \mathrm{~cm})$. The column was washed with one column volume of $0.05 \mathrm{~m}$ sodium phosphate buffer $\mathrm{pH} 7.4$ and $\mathrm{CBG}$ eluted with $0.06 \mathrm{~m}$ alpha-methyl-D-mannoside in the same buffer. This CBG peak of $70 \mathrm{ml}$ was dialyzed and concentrated in a collodion bag. The following chromatography was performed on a hydroxylapatite column $(1.2 \times 45 \mathrm{~cm})$ equilibrated with $0.001 \mathrm{~m}$ sodium phosphate buffer $\mathrm{pH}$ 6.8. The same buffer was used for the elution step. The CBG peak was concentrated and transferred to a QAESephadex A-50 column $(2.2 \times 45 \mathrm{~cm})$, equilibrated with $0.19 \mathrm{M} \mathrm{NaCl}$ in $0.05 \mathrm{M}$ Tris$\mathrm{HCl}$ buffer $\mathrm{pH}$ 8.6. The final elution was performed with a linear gradient $(400 \mathrm{mI})$ from 0.19 to $0.24 \mathrm{M} \mathrm{NaCl}$ in $0.05 \mathrm{~m}$ Tris-HC1 buffer 8.6 in a volume of $75 \mathrm{ml}$. The CBG solution was repeatedly dialyzed in a collodion bag against aqua bidest., frozen, lyophilized and stored at $-20^{\circ} \mathrm{C}$. The $\mathrm{CBG}$ peaks in the eluates from each column were identified using a modification of the $\left[{ }^{3} \mathrm{H}\right]$ cortisol-uptake-test on $5 \mathrm{ml}$ Sephadex $\mathrm{G}-50$ (Horn et al. 1975).

\section{Radioimmunoassay of $C B G$}

Immunization. - Rabbits were immunized with $120 \mu \mathrm{g}$ CBG in complete Freund's adjuvant and $0.5 \mathrm{ml}$ pertussis vaccine antigen using a multiple intradermal injection technique (50 sites) on the back flanks. They were boosted every three weeks with the same technique.

Radioiodination of CBG was done with the chloramine-T-method (Greenwood et al. 1963). The separation of the CBG tracer was performed only on a $1 \mathrm{ml}$ Con ASepharose column. The CBG tracer was eluted with $0.06 \mathrm{~m}$ alpha-methyl-D-mannoside and diluted in $2 \mathrm{~g} / \mathrm{l}$ bovine albumin in $0.05 \mathrm{~m}$ sodium phosphate buffer $\mathrm{pH} 7.4$. The tracer could be used for 8 weeks without further purification.

For the radioimmunoassay $100 \mu \mathrm{l}$ CBG standard solution or 1:100 diluted serum were incubated with $100 \mu$ l CBG tracer and $100 \mu$ it diluied CBG antiserum. The bound/free-separation could be performed by the polyethylene glycol precipitation (Desbuquois \&. Aurbach 1971) or the double antibody technique.

\section{R E S ULT S}

\section{Crileria of purily and characterization}

Electrophoretical methods. - The isolated CBC migrated on polyacrylamide gel electrophoresis and SDS electrophoresis (Maurer 1971) each performed in two different buffer systems $\mathrm{pH} 8.9$ and $\mathrm{pH} 7.0$ and three different gel concentrations $(10,7.5$ and $5 \%$ ) in one homogeneous band. Immunoelectrophoresis and Ouchterlony double diffusion test demonstrated a single precipitation line between $\mathrm{CBG}$ antiserum and $\mathrm{CBG}$ solution and normal human serum, respectively. The overlapping of both precipitation lines indicated identity between endogenous and isolated CBG.

Isoelectric focusing studies revealed a microheterogeneity of 5 different bands in the $\mathrm{pH}$ range of $\mathrm{pH} 3.7-4.2$. In the same $\mathrm{pH}$ area $\mathrm{CBG}$ was detected in the radioimmunoassay as well as the radioactivity of $\left[{ }^{3} \mathrm{H}\right]$ cortisol preincubated with $\mathrm{CBG}$. Neuraminidase treatment of CBG reduced the micro- 
heterogeneity to one major and one minor band in the $\mathrm{pH}$ range of $\mathrm{pH} 6.0$ (Fig. 1).

Analytical ultracentrifugation. - The purity and the homogeneity of the isolated $\mathrm{CBG}$ could be demonstrated by a homogeneous curve in sedimentation velocity runs and by a straight line in the high speed sedimentation equilibrium runs. The sedimentation coefficient corrected to $20^{\circ} \mathrm{C}$ and water (Schachmann 1957; Schachmann \& Edelstein 1966) was calculated to be $3.6 \mathrm{~S}$. Considering a partial specific volume of $0.690 \mathrm{ml} / \mathrm{g}$ derived from the amino acid and carbohydrate composition (Table 1) a molecular weight (Yphantis 1964) of $50700 \pm 2500(\mathrm{n}=4)$ for $\mathrm{CBG}$ was determined. The diffusion coefficient was calculated to be $5.6 \mathrm{D}$, the Stokes radius $38 \AA$ and the frictional coefficient ratio 1.5 .

Quantilative amino acid analysis in two different CBG preparations is summarized in Table 1. The high content of aspartic acid and glutamic acid explains the low isoelectric point of CBG. The carbohydrate composition is shown in the lower part of Table 1.

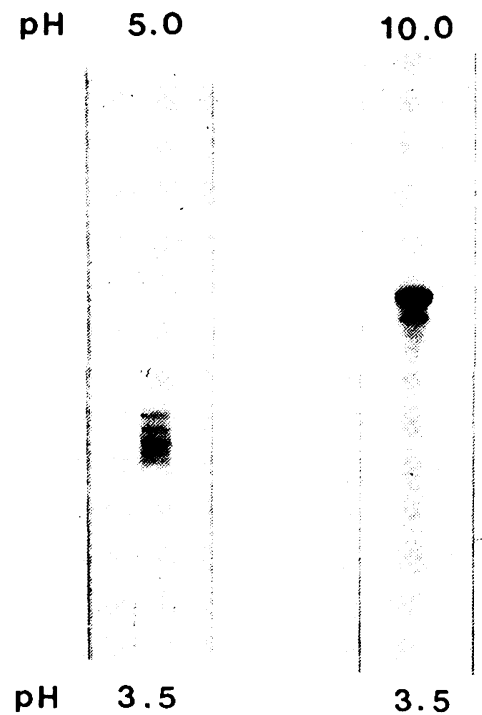

Fig. 1 .

Isoelectric focusing of isolated CBG. Left: untreated $\mathrm{CBG}, \mathrm{pH}$ gradient 3.5-5.0. Right: Desialylated CBG $(0.03 \mathrm{U} / \mathrm{ml}$ neuraminidase, acetate buffer $\mathrm{pH} 5.6 .30 \mathrm{~min}) \mathrm{pH}$ gradient $3.5-10$. 
Table 1.

Amino acid and carbohydrate composition of CBG. The amino acid analysis was performed with two different preparations of CBG, the carbohydrate analysis only with one preparation. Assuming a molecular weight of 50700 the left column indicates the numbers of amino acid residues per mol CBG, the right column the percentage of the single amino acids of the polypeptid residue (molecular weight 32 950). The lower part of the table indicates the carbohydratc composition of the second preparation of $\mathrm{CBG}$.

\begin{tabular}{l|r|r|r|r}
\hline amino acids: & \multicolumn{2}{|c|}{ No. of residues/mol CBG } & \multicolumn{2}{|c}{$\begin{array}{c}\text { g of residue/ } 100 \mathrm{~g} \\
\text { of polypeptid }\end{array}$} \\
\cline { 2 - 5 } preparation & I & II & I & II \\
\hline Lysine & 15 & 15 & 6.7 & 6.7 \\
Histidine & 11 & 12 & 5.2 & 5.7 \\
Arginine & 10 & 10 & 5.3 & 5.3 \\
Aspartic acid & 35 & 37 & 14.1 & 14.9 \\
Threonine & 18 & 17 & 6.5 & 6.1 \\
Serine & 21 & 16 & 6.7 & 5.1 \\
Glutamic acid & 33 & 34 & 14.7 & 2.7 \\
Proline & - & 8 & - & 2.2 \\
Glycine & 11 & 10 & 2.5 & 4.0 \\
Alanine & 14 & 15 & 3.7 &.- \\
Cystine & - & - &.. & 7.4 \\
Valine & 18 & 21 & 6.4 & 5.0 \\
Methionine & 12 & 11 & 5.4 & 7.1 \\
Isoleucine & 15 & 18 & 5.9 & 15.5 \\
Leucine & 35 & 39 & 13.9 & 4.9 \\
Tyrosine & 13 & 9 & 11.8 & \\
Phenylalanine & 23 & 25 & & \\
\hline
\end{tabular}

carbohydrate composition in $\%$ by weight

II

$\begin{array}{lr}\text { Mannose } & 9.5 \\ \text { Galactose } & 5.3 \\ \text { Glucosamine } & 10.3 \\ \text { Sialic acid } & 10.0\end{array}$


The binding of several steroids to CBG was investigated by two different methods, firstly equilibrium dialysis in micro-cells (Dianorm Apparatus, Diachemica AG, Switzerland) as the reference method and secondly, gel filtration on small columns with $2 \mathrm{ml}$ Sephadex G-10 as a very simple method for estimation of the relative affinity constants of several steroids. The binding studies were performed in phosphate buffer $\mathrm{pH} 7.4$ at $4^{\circ} \mathrm{C}$. The incubation time for gel filtration was $15 \mathrm{~min}$, the dialyzing time $8 \mathrm{~h}$. Equilibrium dialysis was performed for four different steroids using firstly the corresponding tracer and secondly $\left[{ }^{3} \mathrm{H}\right]$ cortisol in order to test for cross reactivity between the different steroids and cortisol tracer in CBG binding. There was a large measure of agreement between the calculated binding constants of each method (Table 2). Gel filtration resulted in lower association constants than equilibrium dialysis. This was due to the disturbance of equilibrium during the filtration on Sephadex G-10. The binding constant for cortisol was found to be approximately 8 times lower in gel filtration than in equilibrium dialysis. Utilizing this factor for the correction of the association constants of $17 \alpha$ hydroxy-progesterone, 11-deoxycortisol, progesterone and testosterone, each calculated by displacement of $\left[{ }^{3} \mathrm{H}\right]$ cortisol using gel filtration, the corrected

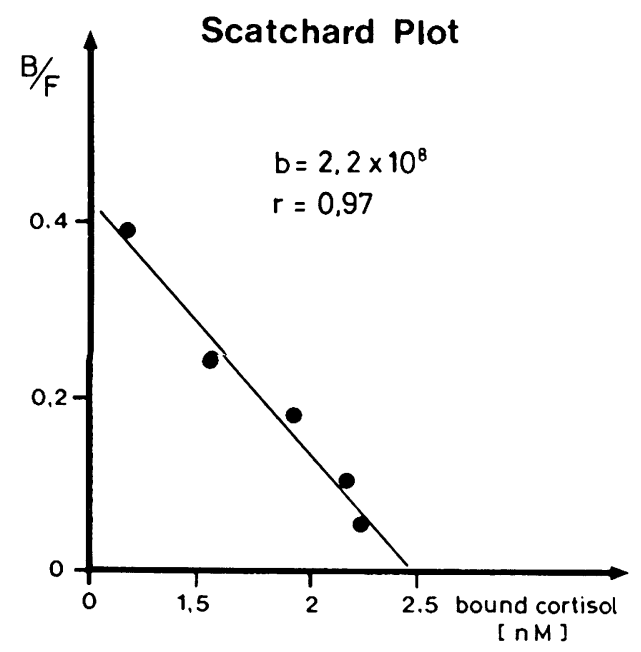

Fig. 2.

Determination of the association constant of cortisol and isolated CBG by means of Scatchard plot. Ordinate: ratio of $\mathrm{CBG}$ bound and free cortisol tracer. Abscissa: amount of bound cortisol, calculated as product of the percentage of $\left[{ }^{3} \mathrm{H}\right] \operatorname{cortisol}(\mathrm{B} / \mathrm{T})$ and the molecular concentration. 
Table 2.

Association constants of different steroids, determined by equilibrium dialysis using the corresponding tracer for each steroid (first column), equilibrium dialysis using $\left[{ }^{3} \mathrm{H}\right]$ cortisol tracer only (second column), and gel filtration on Sephadex G-10 using $\left[{ }^{3} \mathrm{H}\right]$ cortisol tracer only (third column).

For methodological details see text. In the right part of the table the molecular differences of the investigated steroids compared with cortisol are indicated.

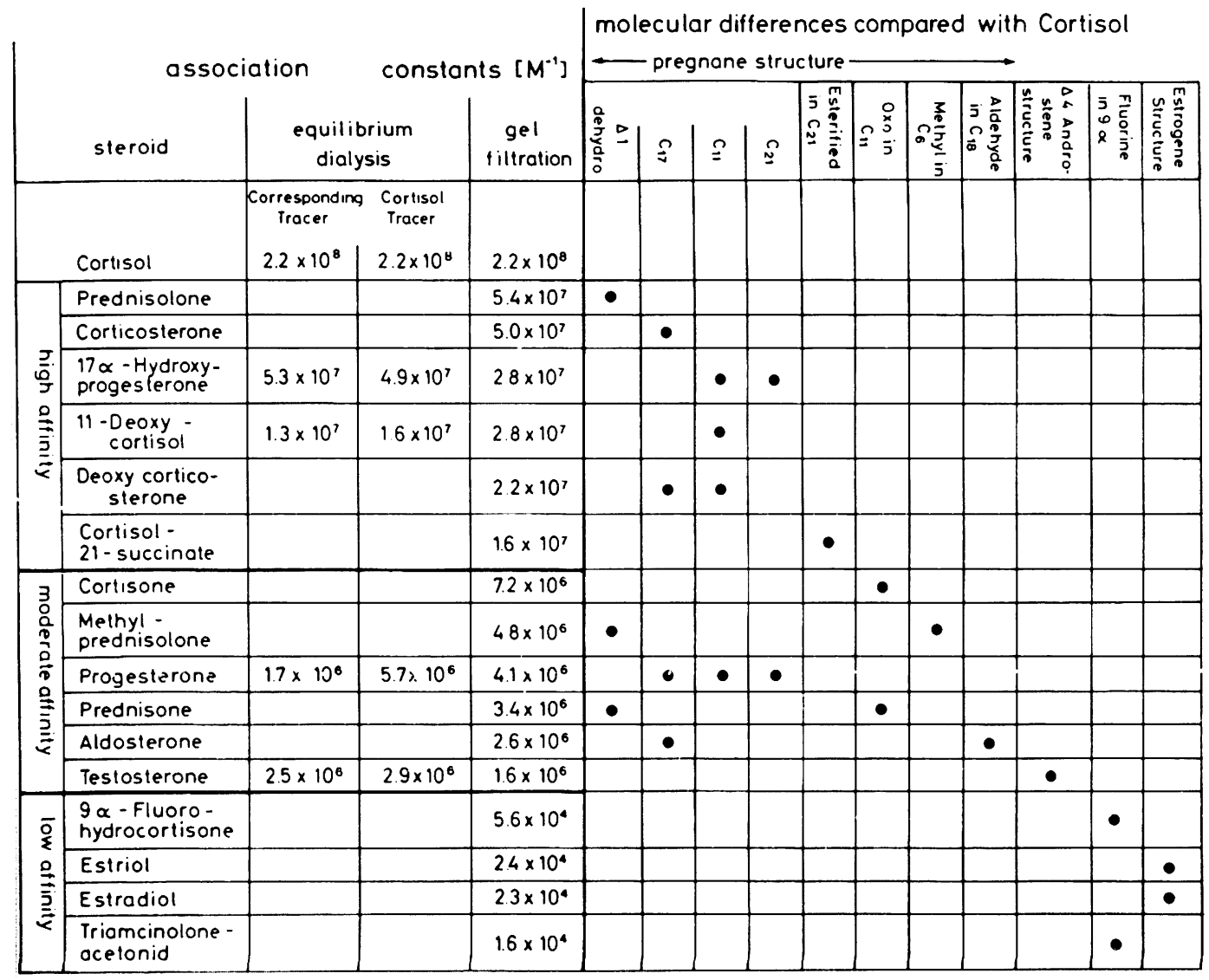

no affinity: Dexamethasone, Ethinylestradiol, Carbenoxolone

values were in the same order of magnitude as found in the equilibrium dialysis (Table 2). The maximal binding capacity calculated by Scatchard analysis was found to be $715 \mu \mathrm{g}$ cortisol per $100 \mathrm{mg}$ CBG indicating an equimolar binding of CBG and cortisol (Fig. 2). By comparing the association constants with the molecular differences of several steroids to cortisol (Table 2) it might be supposed that the binding affinity decreased in dependence on the electron attraction and the size of the substitute. 
Radioimmunological determination of CBG. - The antiserum with the highest titer of 1:160000, determined by 50\% tracer binding, was obtained after the third booster. The maximal tracer binding (specific activity: $31 \mu \mathrm{Ci} / \mu \mathrm{g} \mathrm{CBG}$ ) was nearly $100 \%$. The nonspecific binding without antiserum in the reaction mixture was in the range between 5 to $10 \%$. Using an antiserum dilution of 1:3000 the limit of detection ( $3 \mathrm{sD}$ from the zero standard) was $2 \mathrm{ng}$ CBG per tube. The $50 \%$ intercept was $24 \mathrm{ng}$ CBG per tube, the recovery of added CBG standard in serum was $100 \%$, dilution curves of normal and pregnancy sera were found to be exactly on the calibration curve. The interassay variation coefficient was $7.4 \%$ (mean $3.3 \mathrm{mg} / 100 \mathrm{ml} ; \mathrm{n}=23$ ).

There was no evidence for cross reactivity of CBG antiserum with alpha.macroglobulin, alpha,-haptoglobin, alpha ${ }_{1}$-antitrypsin and albumin in the Ouchterlony double diffusion test, cross reactivity of TBG was excluded in the radioimmunoassay. Cortisol in serum had no effect on the results of CBG determination.

\section{Comparison of $C B G$ and $T B G$ levels in human serum}

$C B G$ levels in human serum. - In 40 control persons between the ages of 15-50 years the range of serum CBG was 2.4-4.4 mg/100 ml. CBG levels of patients with Cushing's syndrome $(n=4)$ and Addison's disease $(n=4)$ werc

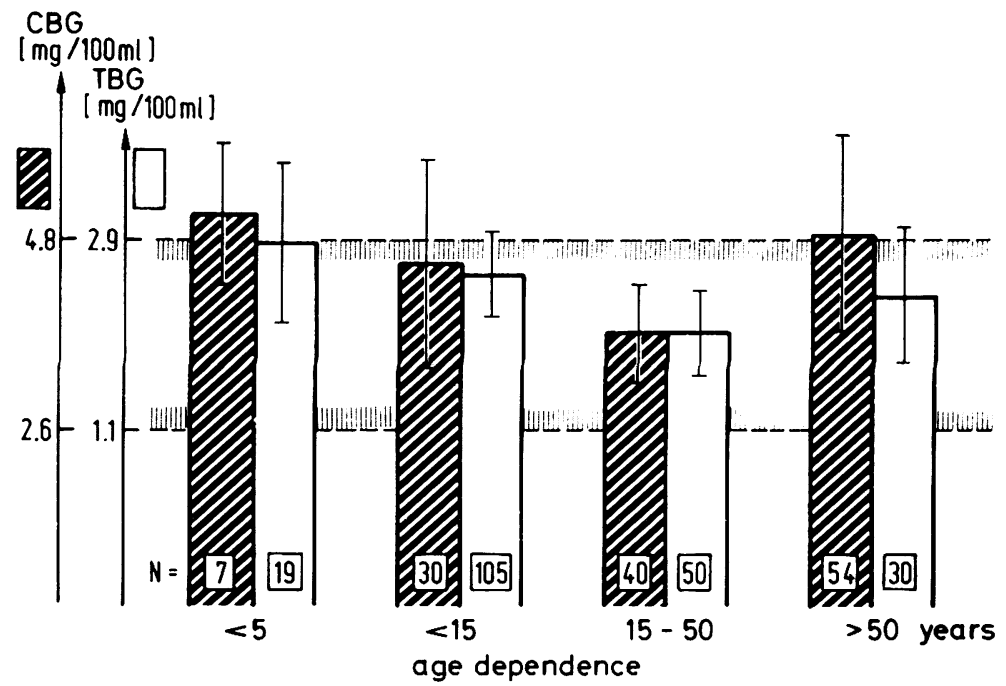

Fig. 3.

Agc dependence of CBG and TBG levels. Hatched columns: CBG levels in $\mathrm{mg} / 100 \mathrm{ml}$. Open columns: $\mathrm{TBG}$ levels in $\mathrm{mg} / 100 \mathrm{ml}$. Hatched lines indicate the normal range of $\mathrm{CBG}$ and $\mathrm{TBG}$ in controls in the age of 15 to 50 years. I mean $\pm \mathrm{sD}$. 


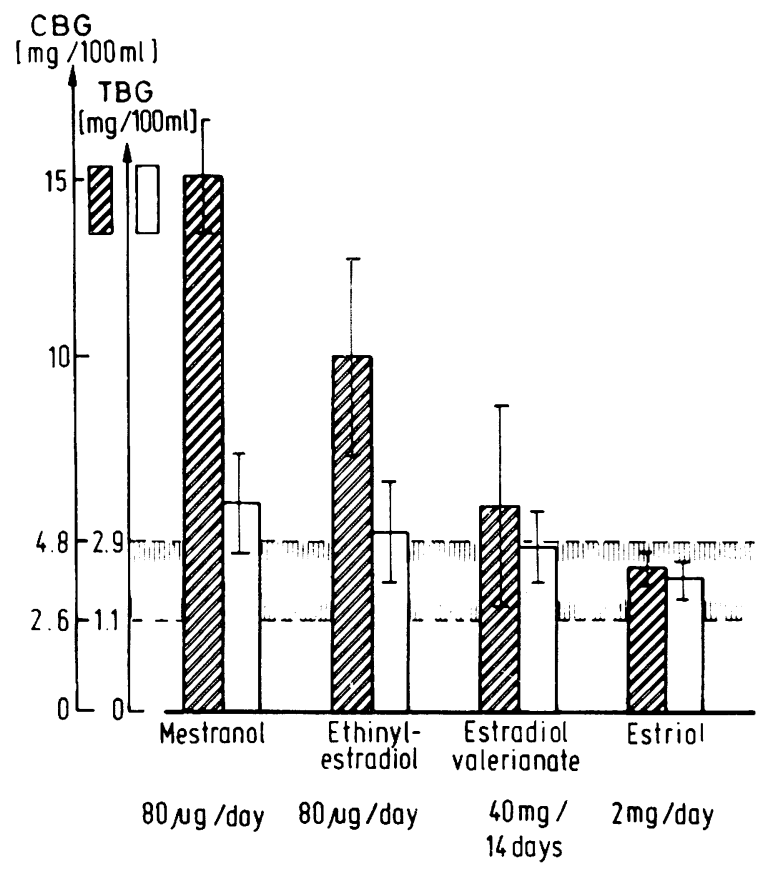

Fig. 4 .

CBG and TBG levels of 4 women subsequently treated with 4 different oestrogen preparations. The hatched columns: CBG levels, the open columns: TBG levels. The hatched lines represent the normal ranges of $\mathrm{CBG}$ and $\mathrm{TBG}$ for the age from 15 to 50 years.

found in this range. In 134 healthy controls the CBG levels showed a biphasic age dependence of CBC levels (Fig. 3). Significant sex differences of CBG and $\mathrm{TBC}$ levels could not be ascertained in any period of life.

Oestrogen dependence of $C B G$ and $T B G$. - In pregnancy $\mathrm{CBG}$ as well as TBG levels increased continuously and reached a plateau during the third trimenon $(6.9 \pm 0.24 \mathrm{mg} / 100 \mathrm{ml}, \mathrm{n}=16)$.

The effect of exogenous oestrogens on CBC and TBG; levels was investigated in four ovarectomized women (lig. 4). The patients were subsequently treated with mestranol $(80 \mu \mathrm{g} /$ day $)$, ethinyl oestradiol $(80 \mu \mathrm{g} /$ day $)$, oestradiol valerianate (40 $\mathrm{mg} / 14$ days), and oestriol ( $2 \mathrm{mg} /$ day), each preparation for four weeks.

Between the phases of oestrogen therapy, a period of placebo administration was inserted for 4 weeks. The response of CBG to oestrogens was more pronounced than the TBG increase. The maximal increase for both was observed after mestranol, whereas oestriol had no effect (Fig. 4). In 10 male 
patients undergoing fosfestrol treatment $\left(H_{0 n v a n}^{*}\right.$ ) for a prostatic carcinoma, a dose-related elevation of CBG levels was observed. Both, CBG and TBG levels reached values of females treated with oestrogens, and again CBG was shown to be the more sensitive indicator of oestrogenic activity.

$C B G$ levels in TBG deficiency states. - TBG deficiency was induced by treatment with Danazol (2,3-isoxazol-derivative of ethinyl-testosterone, Winthrop, Gießen, FRG). Fifteen women were treated with $400 \mathrm{mg}$ Danazol/ day for endometriosis, since Danazol is known to induce endometrium atrophy, and to suppress ovulation and midcycle peaks of gonadotrophins and oestradiol, whereas the mean basal values of LH and oestradiol remain constant (Goebel \& Rjosk 1978). The TBG levels were decreased to $50 \%$ of the initial values after four weeks of therapy, whereas the CBG levels did not change significantly even after 12 weeks (Fig. 5).

In 7 patients with severe chronic diseases such as decompensated liver cirrhosis and chronic heart failure, TBG levels were found to be decreased to $0.72 \pm 0.23 \mathrm{mg} / 100 \mathrm{ml}$. This was interpreted as symptomatic TBG deficiency. In these patients the mean CBG levels were decreased as well to $2.6 \pm 1.0 \mathrm{mg}$ / $100 \mathrm{ml}$. But the decrease of CBG was less pronounced than that of TBG.

In nine patients ( 8 men and 1 female) with genetic TBG deficiency $(0.4 \pm 0.3$ $\mathrm{mg} / 100 \mathrm{ml}, \pm \mathrm{sD}), \mathrm{CBG}$ levels were found to be in the normal range.

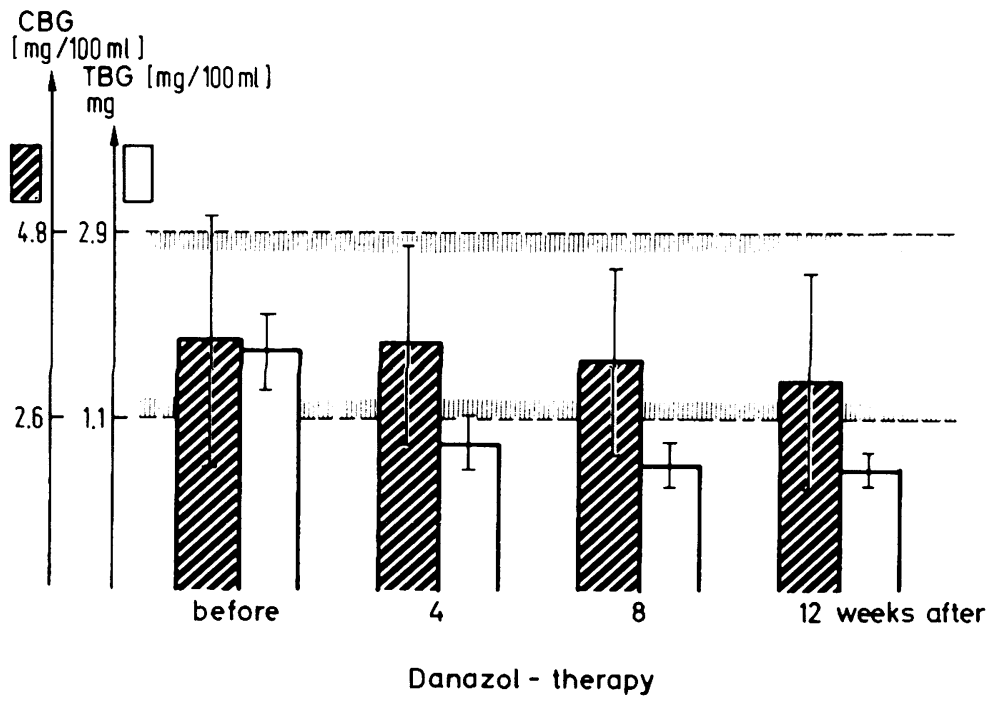

Fig. 5.

CBG and TBG levels during Danazol therapy. Hatched columns: CBG levels, open columns: TBG levels. The hatched lines represent the normal range of CBG and TBG for the age from 15 to 50 years. 
The principle of affinity chromatography as described by Cualrecasas (1970) and used at first by Rosner \& Bradlow (1971) for the isolation of CBG was modified in our study.

Although Rosner \& Bradlow (1971) performed the coupling of cortisol hemisuccinate in pure dioxane and Le Gaillard et al. (1974) thought the coupling in $50 \%$ dimethylformamide not to be practicable, we found that the best results were obtained with the latter method. For displacement of CBG from the cortisol Sepharose, cortisol hemisuccinate addition to the elution buffer was preferred in order to avoid possible denaturation of $\mathrm{CBG}$ which may occur if more aggressive eluents are used.

The observation of Rosner \& Bradlow (1971) who found only CBG and gamma globulins in the eluate of the affinity chromatography column could not be confirmed. Therefore, several additional chromatographic purification steps were required. The overall yield of $20 \%$ after 5 different preparatory steps was satisfactory. The purity of the isolated CBG was shown by a single band in overloaded polyacrylamide and SDS electrophoreses and by ultracentrifugation studies.

The properties of CBG ascertained in our laboratory agreed for the most part with the results of other authors. The molecular weight is reported to be in the range of 49500 to 58500 (Slaumzhite et al. 1966; Muldoon \& Westphal 1967; Le Gaillard et al. 1975). By ultracentrifugation, we determined the value of 50700 , the sedimentation coefficient of $3.6 \mathrm{~S}$ and the partial specific volume of $0.690 \mathrm{ml} / \mathrm{g}$, which corresponds to the values published by Westphal (i971). The hydrodynamic parameters particularly the frictional coefficient ratio suggest that CBG can still be regarded as a globular protein. The Stokes radius of the molecule is about $38 \AA$ which corresponded well with other proteins with a molecular weight in this range. The association constants for cortisol and for other steroids partially obtained by two different methods agreed well with the literature (Weslphal 1977; Stroupe et al. 1978). Only the affinity of progesterone to CBG was found to be lower (Westphal 1971).

The carbohydrate content of $35 \%$ by weight and the mean $\mathrm{N}$-acetylneuraminic acid content of approximately 16 residues per mol isolated CBG was surprisingly high as compared with the literature (Slaumohite el al. 1966; Le Gaillard et al. 1975; Rosner 1976).

After treatment with neuraminidase the microheterogeneity of CBG consisting of 5 single bands was focused to one major band into the alkaline direction. The residual more acidic minor band may be due to incomplete desialylation. Therefore the microheterogeneity of CBG may be due only to the different $\mathrm{N}$-acetylneuraminic acid content as is already established for other glycoproteins and as recently shown for TBG (Horn \& Gärtner 1979). 
Radioimmunological quantilation of $C B G$ in serum. - Although Rosner el al. (1973) and Van Baclen \& De Moor (1974) preferred the subcutaneous or intramuscular application technique using a ten-times higher amount of CBC, a monospecific antiserum was obtained by the intracutaneous injection of approximately $120 \mu \mathrm{g}$ CBG. As the precision and practicability of the radioiminunoassay was satisfactory, the method was preferable to the radial immunodiffusion technique (Rosner et al. 1973; Racadol el al. 1974; Van Baelen \& De Moor 1974) for measuring CBG concentrations.

The CBG levels in serum of healthy adults corresponded well with the values estimated by the earlier published methods (Westphal 1971; Rosner et al. 1973; Racadot et al. 1974: Van Baelen \& De Moor 1974; Rosner 1976).

$C B G$ levels in normal controls. - Elevated binding capacities of CBG in serum have been observed in newborns and infants by several authors ( $D e$ Moor et al. 1962; Angeli et al. 1977; Wagner 1978). These findings could now be ascertained by the direct $C B G$ radioimmunoassay and in addition a further increase of CBG was seen in elder subjects. This biphasic age dependence was parallel with the TBG levels (Horn el al. 197i). Sex differences of CBG or TBG levels could not be ascertained in any period of life. These results were surprising with regard to the known oestrogen influence on the levels of both proteins, therefore apart from the well known oestrogen induced increase of both transport proteins supposedly other factors have an influence on CBG and TBG.

Oestrogen dependence of CBG and TBG levels. - The oestrogen induced increase of CBG and TBG levels, well known from earlier investigations (Doe et al. 1964; Sandberg \& Slanmwhile 1959; Ingbar 1971; Horn el al. 1977; Wagner 1978). was now ascertained by the quantitative and specific radioimmunological determination. The investigation of sera in pregnancy and during oestrogen therapy of women and men demonstrated a more pronounced increase of CBC as compared with TBG. The increase is probably due to an augmented synthesis of this protein as the half-life is identical in controls and oestrogen treated persons (Sandberg el al. 1964). After therapy of four women with supposedly equivalent doses of four different oestrogen preparations, no increase of $\mathrm{CBG}$ and $\mathrm{TBG}$ was found after oestriol. As expected, the increase was significantly higher after ethinyloestradiol as compared with oestradiol valerianate. Surprisingly the most pronounced increase was induced by mestranol, which may be due to its hepatic metabolism (Bird \& Clark 1973).

$C B G$ levels in TBG deficiency stales. - During Danazol therapy, only a decrease of the TBG levels was observed, while the CBG levels did not change. During the Danazol therapy, clinical signs of peripheral oestrogen deficiency were observed despite of normal oestradiol levels. There is possibly an inter- 
ference of Danazol and oestrogens on liver cell receptors, which effects only TBG decreases. Likewise, the decrease of TBG levels in catabolic states was more pronounced than that of $\mathrm{CBC}$. These differences in the behaviour of CBG and TBG under various hormonal and metabolic influences cannot yet be explained.

No coincident genetic defects of the two different transport proteins have been observed.

\section{R E F E R E N C E S}

Angeli A.. Frajria R., Richiardi L., Agrimonli F. \& Gaidano G.: Clin. chim. Acta i (1977) 1 .

Bird C. E. \& Clark A. F.: J. clin. Endocr. 36 (1973) 296.

Cuatrecasas P.: J. biol. Chem. 245 (1970) 3059.

Daughaday W. H.: J. clin. Invest. 35 (1956a) 1428.

Daughaday W. H.: J. clin. Invest. 35 (1956b) 1434.

De Moor P., Deckx R., Raus J. \& Denef C.: Metabolism 12 (1963) 592.

De Moor P., Heirwegh K., Heremans J. F. \& Declerck-Raskin M.: J. clin. Invest. 41 (1962) 816.

Desbuquois B. \& Aurbach G. D.: J. clin. Endocr. 33 (1971) 732.

Doe R. P., Fernandez R. N. \& Seal U. S.: J. clin. Endocr. 24 (1964) 1029.

Goebel R. \& Rjosk H. K.: Geburtsh. u. Frauenheilk. 38 (1978) 932.

Greenwood F. C., Hunter W. M. \& Glover J. S.: Biochem. J. 89 (1963) 114.

Horn K. \& Gärtner R.: Acta endocr. (Kbh.) Suppl. 225 (1979) 433.

Horn K.. Henner J.. Müller O. A. \& Scriba P C.: Z. klin. Chem. 13 (1975) 173.

Horn K., Kubiczek Th., Pickardt C. R. \& Scriba P. C.: Klin. Wschr. 55 (1977) 881.

Ingbar S. H. In: Werner S. C. and Ingbar S. H.. Eds. The Thyroid. Harper and Row, New York (1971) 243.

Le Gaillard F., Han K. K. \& Dautrevaux M.: Biochimie 57 (1975) 559.

Le Gaillard F.. Racadot A.. Racadol-Leroy N. \& Dautrevaux M.: Biochimie 56 (1974) 99.

Maurer H. R.: Disc Electrophoresis and Related Techniques of Polyacrylamide Gel Electrophoresis. De Gruyter, Berlin-New York (1971).

Muldoon T. B. \& Westphal U.: J. biol. Chem. 242 (1967) 5636.

Murphy B. E. P. \& Pattee C. J.: J. clin. Endocr. 23 (1963) 459.

Racadot A.. Racadot-Leroy N. \& Dautrevaux M.: Lille Med. 19/9 (1974) 938.

Radola B. J. \& Graesslin D.: Electrofocusing and Isotachophoresis, De Gruyter, Berlin-

New York (1977).

Rosner W. In: Jamieson G. A. and Greenwalt T. J., Eds. The binding of steroid hormones in human serum. Progress in Clinical and Biological Research, Vol. j. Elsevier, Amsterdam (1976) 377.

Rosner W. \& Bradlow H. L.: J. clin. Endocr. 3.3 (1971) 193.

Rosner W., Darmstadt R. A. \& Toppel S.: J. clin. Endocr. 37 (1973) 983.

Sandberg A. A. \& Slaunwhite W. R. jr.: J. clin. Invest. 38 (1959) 1290.

Sandberg A. A. \& Slaunwhite W. R. jr.: J. clin. Invest. 42 (1963) 51.

Sandberg A. A., Woodruff M. \& Rosenthal H.: J. clin. Invest. 43 (1964) 461.

Schachmann H. K.: Methods in Enzymology 4 (1957) 32.

Schachmann H. K. \& Edelstein S. J.: Biochemistry 5 (1966) 2681. 
Schwartz U. \& Hammerstein J.: Z. klin. Chem. 13 (1975) 291.

Slaunwhite W. R. jr., Lockie G. N., Back N. \& Sandberg A. A.: Science 135 (1962) 1062.

Slaunwhite W. R. \& Sandberg A. A.: J. clin. Invest. 38 (1959) 384.

Slaunwhite W. R. jr., Schneider S., Wissler F. C. \& Sandberg A. A.: Biochemistry 5 (1966) 3527.

Stroupe S. D., Gray R. D. \& Westphal U.: FEBS Letters 86 (1978) 61.

$V$ an Baelen H. \& De Moor P.: J. clin. Endocr. 39 (1974) 160.

Wagner R. K.: Acta endocr. (Kbh.) Suppl. 218 (1978) 5.

Werthamer S.. Samuels A. J. \& Amaral J.: J. biol. Chem. 248 (1973) 6398.

Westphal U.: Steroid-Protein Interactions. Monographs on Endocrinology. SpringerVerlag, Berlin-Heidelberg-New York (1971).

Westphal U.: Klin. Wschr. 55 (1977) 877.

Wong K. C., Kornel L., Bezkorovainy A. \& Murphy B. E. P.: Biochim. biophys. Acta (Amst.) 328 (1973) 133.

Yphantis D. A.: Biochemistry 3 (1964) 297.

Received on January 18th, 1979. 